\title{
Possibilities of Linking Results of EURAMET and COOMET Key Comparisons for Power
}

\section{O. Velychko ${ }^{1}$, T. Gordiyenko ${ }^{2}$}

1 State Enterprise "All-Ukrainian state research and production center for standardization, metrology, certification and consumers' rights protection" (SE "Ukrmetrteststandart"), Metrologichna Str., 4, 03143, Kyiv, Ukraine velychko@ukrcsm.kiev.ua

2 Odesa State Academy of Technical Regulations and Quality (OSATRQ), Kovalska Str., 15, 65020, Odesa, Ukraine t_gord@hotmail.com

\section{Abstract}

The outcomes of the CIPM MRA are the internationally recognized Calibration and Measurement Capabilities (CMCs) of the participants of comparisons. Main results of the participating laboratories of National Metrology Institutes (NMIs) and Designated Institutes (DIs), measuring the same power in a framework EURAMET.EM-K5.1 and COOMET.EM-K5 key comparisons (KCs), are presented. 12 NMIs/DIs took part in EURAMET.EM-K5.1 KC. 13 NMIs/DIs participated in COOMET.EM-K5 KC. UME (Turkey), UMTS (Ukraine) and SMU (Slovakia) were joint participants in EURAMET.EM-K5.1 and COOMET.EM-K5 KCs.

For Global Metrological Traceability, it is advisable to use a methodology for linking the results of Constative Committees (CCs) KC to Regional Metrology Organizations (RMOs) KC. The linking procedure of RMOs KC with respect to reference value of CC KC is described. Linked results of EURAMET.EM-K5.1 and COOMET.EM-K5 KCs for power are presented. Special conclusions on the results of UME, UMTS and SMU who participated in both KCs are presented.

Keywords: key comparison; reference value; measurement uncertainty; National Metrology Institute; linking.

Received: 12.11 .2019

Edited: 27.11.2019

Approved for publication: 29.11.2019

\section{Introduction}

The Mutual Recognition Arrangement (MRA) of the International Committee for Weights and Measures (CIPM) [1] plays an important role for Global Metrological Traceability (GMT) [2]. Key comparisons (KCs) of the national measurement standards in different fields of measurements are the special comparisons of National Metrology Institutes (NMIs) and Designated Institutes (DIs) in the frame of Constative Committee (CC) of CIPM and Regional Metrology Organizations (RMOs). KCs of RMOs are equivalent to $\mathrm{CC} \mathrm{KCs}$.

For all KCs (CCs and RMOs) the reference value $(\mathrm{RV})$ of $\mathrm{KC}$ and degree of equivalence (DoE) of the national measurement standards with corresponding uncertainty are established [3]. DoE is obtained as the deviation of its measurement result from the KC $\mathrm{RV}$, together with the uncertainty associated with this deviation according to the CIPM MRA. DoE derived from an RMO KC has the same status as that derived from a CC KC. The CIPM MRA describes in general how the data of $\mathrm{KC}$ will be evaluated, but many different ways of evaluating $\mathrm{KC}$ data have been suggested [4-6].
RMOs have procedures for carry out the comparisons, in particular the Euro-Asian Cooperation of National Metrological Institutions (COOMET) and the European Association of National Metrology Institutes (EURAMET). Results of KCs $\mathrm{CC}$ and KCs RMOs are published in special Key Comparison Database (KCDB) of the International Bureau of Weights and Measures (BIPM) [7]. Only COOMET has guidelines on $\mathrm{KC}$ data evaluation [8].

The outcomes of the CIPM MRA are the internationally recognized Calibration and Measurement Capabilities (CMCs) of the participating in comparisons. The internationally recognized NMIs and DIs CMCs are those that are published in the KCDB of BIPM [9, 10].

Establishment of GMT is carried out in accordance with procedures through international comparisons of the national measurement standards of NMIs or DIs. For GMT, it is advisable to use a methodology for linking the results of $\mathrm{CC} \mathrm{KC}$ to $\mathrm{RMO} \mathrm{KC}$ and $\mathrm{RMO} \mathrm{KC}$ to other analogical RMO KC [11, 12]. Refer methodologies can be used for practical assessment of results of specific RMOs KCs as an extension of the technical basis of confirmation of CMCs of NMIs or DIs. 


\section{Brief review of performed key comparisons of power}

The Consultative Committee for Electricity and Magnetism (CCEM) of CIPM was a sponsor of international comparisons of the national measurement standards of power between laboratories of different NMIs and DIs in the CIPM MRA framework. From 1995 to 2000, CCEM-K5 KC for 50/60 Hz alternating current (AC) power was carried out [13]. 15 NMIs/ DIs participated in this $\mathrm{KC}$, which are the members of five RMOs: EURAMET, APMP, COOMET, SIM and AFRIMET. The NIST (USA) was the pilot laboratory of this $\mathrm{KC}$.

From 2003 to 2008, EURAMET.EM-K5.1 KC for $50 / 60 \mathrm{~Hz}$ power was carried out [14]. 12 NMIs/ DIs participated in this $\mathrm{KC}$, which are the members of three RMOs: EURAMET, APMP and COOMET. The UME (Turkey) was the pilot laboratory of this KC. SE "Ukrmetrteststandart" (UMTS, Ukraine) took part as the participant in this $\mathrm{KC}$ with the aim of publishing CMCs for power in the KCDB of the BIPM. PTB (Germany) was linking NMI for the linking process between CCEM-K5 KC and EURAMET.EM-K5.1 $\mathrm{KC}$ because of participating in CCEM-K5.

From 2016 to 2018, COOMET.EM-K5 KC $[15,16]$ for power was carried out. 13 NMIs/DIs participated in this $\mathrm{KC}$, which are the members of five RMOs: COOMET, EURAMET, APMP, AFRIMET and GULFMET. UMTS (Ukraine) was the pilot laboratory. NIM (China) and VNIIM (Russia) were linking NMIs for the linking process between CCEM-K5 KC and COOMET.EM-K5 KC because of participating in CCEM-K5.

The link between the CCEM-K5, EURAMET. EM-K5\&K5.1, SIM.EM-K5 and COOMET.EM-K5 was established [17].

RVs and standard uncertainties for EURAMET. EM-K5.1 and COOMET.EM-K5 KCs at frequency $53 \mathrm{~Hz}$ for power factor (PF) 1.0, 0.5 Lag, 0.5 Lead, $0.0 \mathrm{Lag}, 0.0 \mathrm{Lead}$ are presented in Table 1.

Table 1

RVs and uncertainties for EURAMET.EM-K5.1 and COOMET.EM-K5 KCs

\begin{tabular}{|c|c|c|c|c|}
\hline \multirow{2}{*}{$\begin{array}{l}\text { Power } \\
\text { factor }\end{array}$} & $\begin{array}{c}X_{\text {KCRV }} \\
\mu \mathrm{W} /(\mathrm{VA})\end{array}$ & $\begin{array}{c}\mathrm{u}_{\mathrm{KCRV}}, \\
\mu \mathrm{W} /(\mathrm{VA})\end{array}$ & $\begin{array}{c}X_{\mathrm{KCRV}} \\
\mu \mathrm{W} /(\mathrm{VA}) \\
\end{array}$ & $\begin{array}{c}\mathrm{u}_{\text {KCRV }}, \\
\mu \mathrm{W} / \text { (VA) }\end{array}$ \\
\hline & \multicolumn{2}{|c|}{ EURAMET.EM-K5.1 } & \multicolumn{2}{|c|}{ COOMET.EM-K5 } \\
\hline 1.0 & -1.5 & 3.2 & -2.1 & 2.9 \\
\hline $0.5 \mathrm{Lag}$ & -0.7 & 3.3 & 8.0 & 2.3 \\
\hline $0.5 \mathrm{Lead}$ & -2.1 & 3.3 & -9.7 & 2.3 \\
\hline $0.0 \mathrm{Lag}$ & -0.1 & 3.2 & 6.4 & 2.6 \\
\hline $0.0 \mathrm{Lead}$ & -1.5 & 3.1 & -10.2 & 2.6 \\
\hline
\end{tabular}

The degrees of equivalence of $i$-th NMI or DIs and its expanded uncertainties with respect to the KC $\mathrm{RV}$ are estimated as [8]:

$$
\begin{gathered}
D_{\mathrm{i}}=x_{\mathrm{i}}-X_{\text {KCRV }}, \\
U^{2}\left(D_{\mathrm{i}}\right)=U^{2}\left(x_{\mathrm{i}}\right)+U^{2}\left(X_{\text {KCRV }}\right),
\end{gathered}
$$

where $x_{\mathrm{i}}$ is relative deviations from nominal values $i$-th NMI or DIs in EURAMET.EM-K5.1 or COOMET. EM-K5 KCs;

$X_{\mathrm{KCRV}}$ is RV of EURAMET.EM-K5.1 or COOMET. EM-K5 KCs;

$U\left(x_{\mathrm{i}}\right)$ is expanded uncertainty of relative deviations from nominal values $i$-th NMI or DIs in EURAMET. EM-K5.1 or COOMET.EM-K5 KCs;

$U\left(X_{\text {KCRV }}\right)$ is expanded uncertainty of $\mathrm{RV}$ of EURAMET.EM-K5.1 or COOMET.EM-K5 KCs.

Result for all NMI/DIs participants of both KCs satisfies the condition of performance and characterizes good data consistency.

\section{Evaluation of results of EURAMET and COOMET key comparisons}

The DoE of $i$-th NMI/DI with respect to linking to CCEM-K5 is estimated as

$$
d_{\mathrm{i}}=D_{\mathrm{i}}+\Delta
$$

where $D_{\mathrm{i}}$ is result from EURAMET.EM-K5.1 or COOMET.EM-K5 for a NMI participant in respectively $\mathrm{KC}$ only; $d_{\mathrm{i}}$ is best estimate of result from $i$-th NMI/DI to linking to CCEM-K5.

Measurements from the linking NMIs/DIs provide estimates

$$
\Delta_{i \mathrm{LINK}}=d_{i \mathrm{LINK}}-D_{i \mathrm{LINK}}
$$

for the correction $\Delta$.

The correction $\Delta$ is then calculated as the weighted mean of the linking NMIs/DIs estimates, that is:

$$
\Delta=\sum_{i \mathrm{LINK}} w_{i \mathrm{LINK}} \Delta_{i \mathrm{LINK}},
$$

where: $d_{i \mathrm{LINK}}$ is result from CCEM-K5 for a linking NMIs/DIs;

$D_{i L I N K}$ is result from EURAMET.EM-K5.1 or COOMET.EM-K5 for a linking NMI/DI;

$$
w_{i \mathrm{LINK}}=\frac{s^{2}(\Delta)}{s^{2}\left(\Delta_{i \mathrm{LINK}}\right)} ; s^{2}(\Delta)=1 / \sum_{i \mathrm{LNK}} \frac{1}{s^{2}\left(\Delta_{i \mathrm{LINK}}\right)} .
$$

$s\left(\Delta_{i \mathrm{LINK}}\right)$ is the uncertainty associated with $\Delta_{i \mathrm{LINK}}$ given as the root-sum-square of $u_{\mathrm{T}}, u\left(p_{\mathrm{i}}\right), r_{\mathrm{iLNK}}$, where $u_{\mathrm{T}}$ is the transfer uncertainty in the CCEM-K5 comparison; $u\left(p_{\mathrm{i}}\right)$ is the transfer uncertainty in the EURAMET. EM-K5.1 or COOMET.EM-K5 comparison;

$r_{i \text { LNK }}$ is the uncertainty associated with the imperfect reproducibility of the results of $\mathrm{NMI} i_{\text {LINK }}$ in the time period spanning its two measurements (whence the factor of 2 for this term in the RSS equation) in the CCEM-K5 and EURAMET.EM-K5.1 or COOMET.EM-K5 comparisons.

The best estimate of the result from $i$-th NMI/DI that it had participating in CCEM-K5 is calculated. The standard uncertainty $u^{2}\left(d_{\mathrm{i}}\right)$ is calculated as:

$u^{2}\left(d_{\mathrm{i}}\right)=u^{2}\left(D_{\mathrm{i}}\right)+u^{2}(\Delta)=u^{2}\left(D_{\mathrm{i}}\right)+s^{2}(\Delta)+u^{2}\left(m_{\mathrm{ref}}\right),(7)$ 
where: $u\left(m_{\mathrm{ref}}\right)$ is the uncertainty in the CCEM-K5 KC RV.

The expanded uncertainty is $U\left(d_{\mathrm{i}}\right)=k_{d_{\mathrm{i}}} u\left(d_{\mathrm{i}}\right)$ where is chosen $k_{d_{i}}=2$ to give $95 \%$ coverage.

Results of NMIs/DIs in EURAMET.EM-K5.1 and COOMET.EM-K5 KCs at frequency of $53 \mathrm{~Hz}$ for PF 1.0, 0.5 Lag, 0.5 Lead, 0.0 Lag, 0.0 Lead were linked with respect to the KC RV of CCEM-K5 KC (only for CIPM MRA members) and are presented in [14, 15], Table 2, 3 respectively and on Fig. $1-5$. UME (Turkey), UMTS (Ukraine) and SMU (Slovakia) were joint participants in EURAMET.EM-K5.1 and COOMET.EM-K5 KCs. The sign "*" (only for COOMET.EM-K5 KC) indicates those NMIs/DIs that participated in both comparisons and have two different results.

Table 2

DoE of NMIs/DIs in EURAMET.EM-K5.1 KC

\begin{tabular}{|l|c|c|c|c|c|}
\hline \multirow{2}{*}{ NMI/DI } & \multicolumn{2}{|c|}{$\begin{array}{c}\mathrm{D}_{\mathrm{i}}, \\
\mu \mathrm{W} /(\mathrm{VA})\end{array}$} & $\begin{array}{c}\mathrm{U}\left(\mathrm{D}_{\mathrm{i}}\right) \\
\mu \mathrm{W} /(\mathrm{VA})\end{array}$ & $\begin{array}{c}\mathrm{D}_{\mathrm{i}}, \\
\mu \mathrm{W} /(\mathrm{VA})\end{array}$ & $\begin{array}{c}\mathrm{U}\left(\mathrm{D}_{\mathrm{i}}\right) \\
\mu \mathrm{W} /(\mathrm{VA})\end{array}$ \\
\cline { 2 - 6 } & \multicolumn{2}{|c|}{$\mathrm{PF}=1.0$} & \multicolumn{2}{c|}{$\mathrm{PF}=0.5 \mathrm{Lag}$} \\
\hline BIM & -14 & 74 & -2 & 99 \\
\hline LNE & 5 & 32 & 7 & 62 \\
\hline MKEH & 8 & 64 & 9 & 62 \\
\hline INM (RO) & 24 & 83 & 8 & 83 \\
\hline DMDM & 23 & 48 & 46 & 40 \\
\hline MIKES & 6 & 35 & 11 & 29 \\
\hline VSL & -15 & 19 & -4 & 23 \\
\hline NPLI & -15 & 81 & 10 & 67 \\
\hline SMU & 16 & 60 & 15 & 23 \\
\hline UMTS & 18 & 34 & 77 & 93 \\
\hline UME & 0 & 25 & 9 & 24 \\
\hline NMI/DI & $\mathrm{PF}=0.5$ Lead & $\mathrm{PF}=0.0 \mathrm{Lag}$ \\
\hline BIM & 2 & 95 & 1 & 103 \\
\hline LNE & -5 & 23 & 7 & 18 \\
\hline MKEH & -12 & 62 & 1 & 62 \\
\hline INM (RO) & 25 & 83 & -16 & 83 \\
\hline DMDM & 17 & 40 & 14 & 38 \\
\hline MIKES & 0 & 29 & 3 & 28 \\
\hline VSL & -23 & 23 & 14 & 24 \\
\hline NPLI & 3 & 67 & -8 & 63 \\
\hline SMU & 18 & 62 & -11 & 63 \\
\hline UMTS & -54 & 93 & 19 & 155 \\
\hline UME & -6 & 24 & -1 & 24 \\
\hline NMI/DI & PF $=0.0$ Lead & & - \\
\hline BIM & 19 & 105 & - & - \\
\hline LNE & -5 & 19 & - & - \\
\hline MKEH & -19 & 62 & - & - \\
\hline INM (RO) & 23 & 83 & - & - \\
\hline DMDM & -9 & 39 & - & - \\
\hline MIKES & 0 & 28 & - & - \\
\hline VSL & 4 & 25 & - & - \\
\hline NPLI & 12 & 64 & - & - \\
\hline SMU & 4 & 64 & - & - \\
\hline UMTS & -9 & 147 & - & - \\
\hline UME & -9 & 25 & - & - \\
\hline
\end{tabular}

Table 3

DoE of NMIs/DIs in COOMET.EM-K5 KC

\begin{tabular}{|c|c|c|c|c|}
\hline \multirow[t]{2}{*}{ NMI/DI } & \begin{tabular}{|c|}
$\mathrm{D}_{\mathrm{i}}$, \\
$\mu \mathrm{W} /(\mathrm{VA})$
\end{tabular} & $\begin{array}{c}\mathrm{U}\left(\mathrm{D}_{\mathrm{i}}\right) \\
\mu \mathrm{W} /(\mathrm{VA})\end{array}$ & $\begin{array}{c}\mathrm{D}_{\mathrm{i}} \\
\mu \mathrm{W} /(\mathrm{VA})\end{array}$ & $\begin{array}{c}\mathrm{U}\left(\mathrm{D}_{\mathrm{i}}\right) \\
\mu \mathrm{W} /(\mathrm{VA})\end{array}$ \\
\hline & \multicolumn{2}{|c|}{$\mathrm{PF}=1.0$} & \multicolumn{2}{|c|}{$\mathrm{PF}=0.5 \mathrm{Lag}$} \\
\hline UME* & -6 & 27 & -12 & 22 \\
\hline UMTS* & 4 & 25 & -4 & 27 \\
\hline SMU* & -50 & 60 & -1 & 70 \\
\hline BelGIM & 2 & 45 & -10 & 42 \\
\hline GEOSTM & 18 & 91 & 9 & 136 \\
\hline MASM & 4 & 77 & 24 & 115 \\
\hline QCC EMI & -7 & 28 & -6 & 25 \\
\hline NIS & -5 & 40 & 22 & 37 \\
\hline $\begin{array}{l}\text { SASO- } \\
\text { NMCC }\end{array}$ & -15 & 43 & -21 & 40 \\
\hline NMI/DI & \multicolumn{2}{|c|}{$\mathrm{PF}=0.5 \mathrm{Lead}$} & \multicolumn{2}{|c|}{$\mathrm{PF}=0.0 \mathrm{Lag}$} \\
\hline $\mathrm{UME}^{*}$ & 4 & 22 & -15 & 23 \\
\hline UMTS* & 5 & 27 & -3 & 24 \\
\hline SMU* & -12 & 70 & 21 & 78 \\
\hline BelGIM & 4 & 42 & -10 & 41 \\
\hline GEOSTM & 2 & 136 & 5 & 203 \\
\hline MASM & -26 & 77 & 21 & 84 \\
\hline QCC EMI & -3 & 25 & 1 & 21 \\
\hline NIS & 22 & 38 & -31 & 41 \\
\hline $\begin{array}{l}\text { SASO- } \\
\text { NMCC }\end{array}$ & 6 & 40 & -3 & 24 \\
\hline NMI/DI & \multicolumn{2}{|c|}{$\mathrm{PF}=0.0 \mathrm{Lead}$} & \multicolumn{2}{|c|}{-} \\
\hline $\mathrm{UME}^{*}$ & 5 & 23 & - & - \\
\hline UMTS* & 6 & 25 & - & - \\
\hline SMU* & 56 & 78 & - & - \\
\hline BelGIM & 8 & 41 & - & - \\
\hline GEOSTM & -8 & 203 & - & - \\
\hline MASM & -23 & 84 & - & - \\
\hline QCC EMI & 2 & 21 & - & - \\
\hline NIS & -21 & 39 & - & - \\
\hline $\begin{array}{l}\text { SASO- } \\
\text { NMCC }\end{array}$ & 14 & 41 & - & - \\
\hline
\end{tabular}

DoE difference of NMIs/DIs in COOMET.EM$\mathrm{K} 5$ and EURAMET.EM-K5.1 KCs at frequency of $53 \mathrm{~Hz}$ for PF 1.0, 0.5 Lag, 0.5 Lead, 0.0 Lag, 0.0 Lead was calculated by formula:

$$
\Delta_{\mathrm{RK}}=D_{i \mathrm{~K} 5}-D_{i \mathrm{~K} 5.1} .
$$

DoE uncertainty difference of NMIs/DIs in COOMET.EM-K5 and EURAMET.EM-K5.1 KCs at frequency of $53 \mathrm{~Hz}$ for PF 1.0, 0.5 Lag, 0.5 Lead, $0.0 \mathrm{Lag}, 0.0$ Lead was calculated by formula:

$$
\Delta U_{\mathrm{RK}}=U\left(D_{i \mathrm{~K} 5}\right)-U\left(D_{i \mathrm{~K} 5.1}\right) .
$$

DoE difference (the smaller the number module, the better) and DoE uncertainty difference (the sign "-" means less uncertainty) of NMIs/DIs in COOMET. EM-K5 and EURAMET.EM-K5.1 KCs are presented in Table 4. 


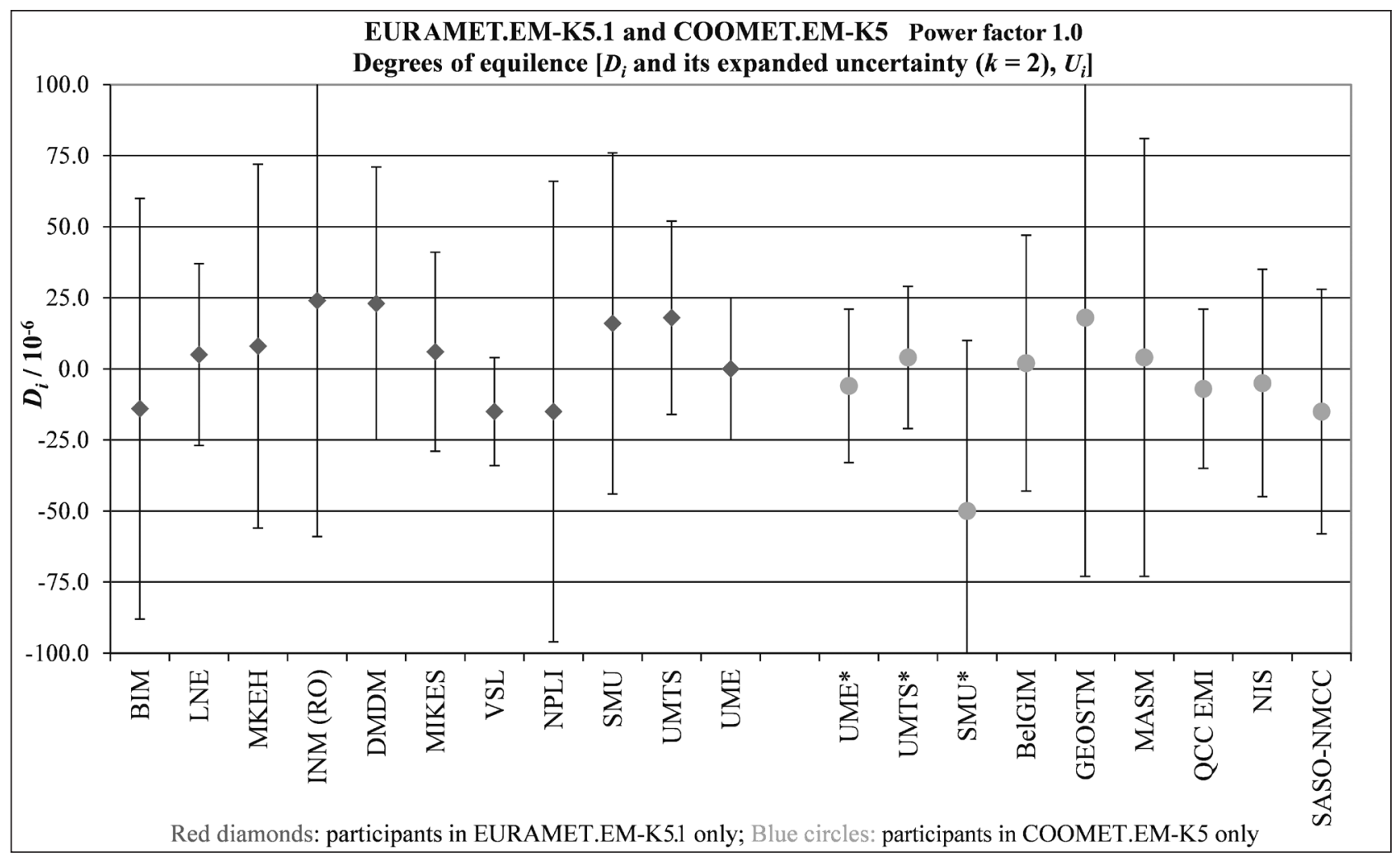

Fig. 1. DoE of NMIs/DIs in EURAMET.EM-K5.1 and COOMET.EM-K5 KCs in terms of RV $\mathrm{K}_{5}$ for PF 1.0

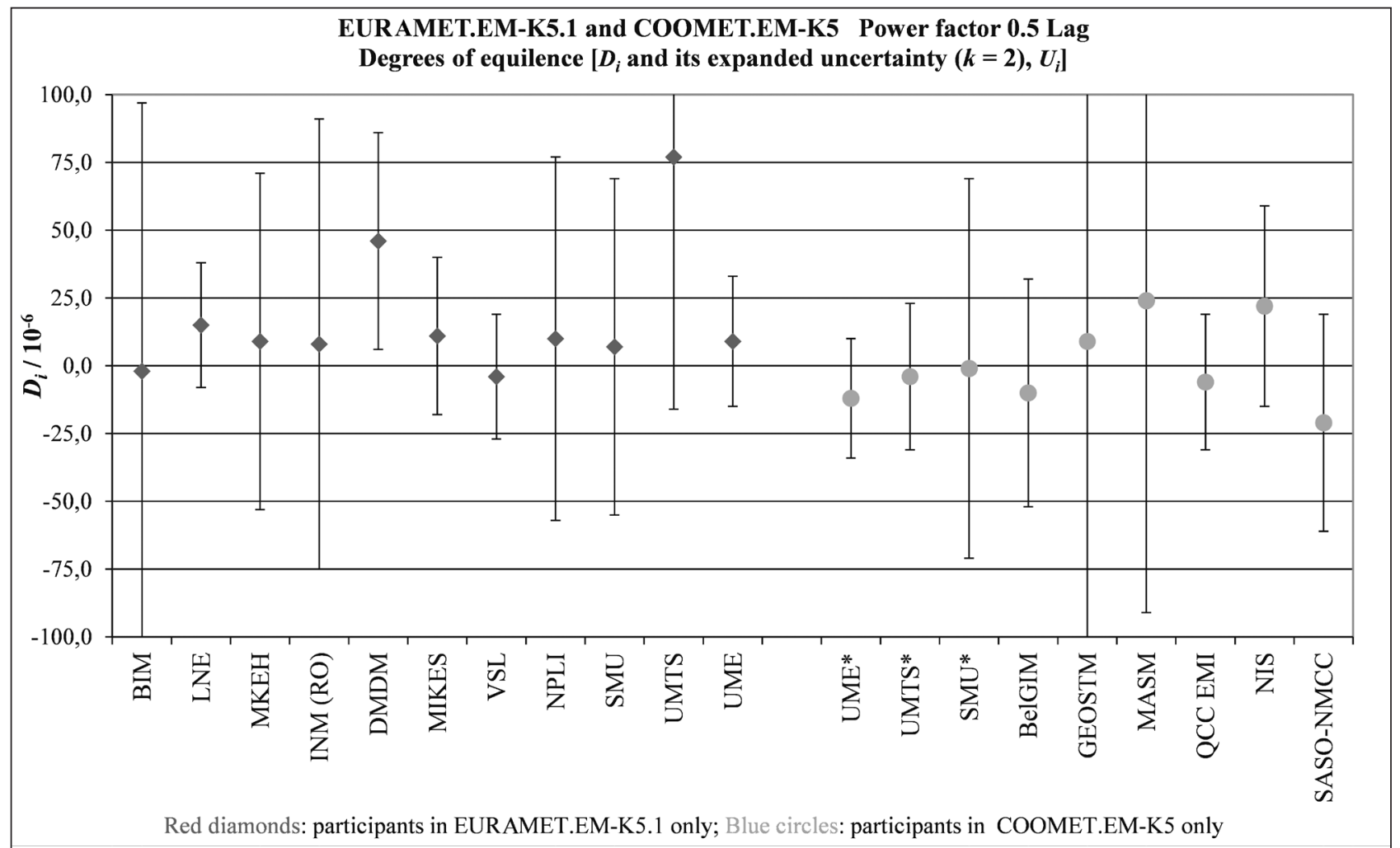

Fig. 2. DoE of NMIs/DIs in EURAMET.EM-K5.1 and COOMET.EM-K5 KCs in terms of RV $\mathrm{K}_{5}$ for PF 0.5 Lag 


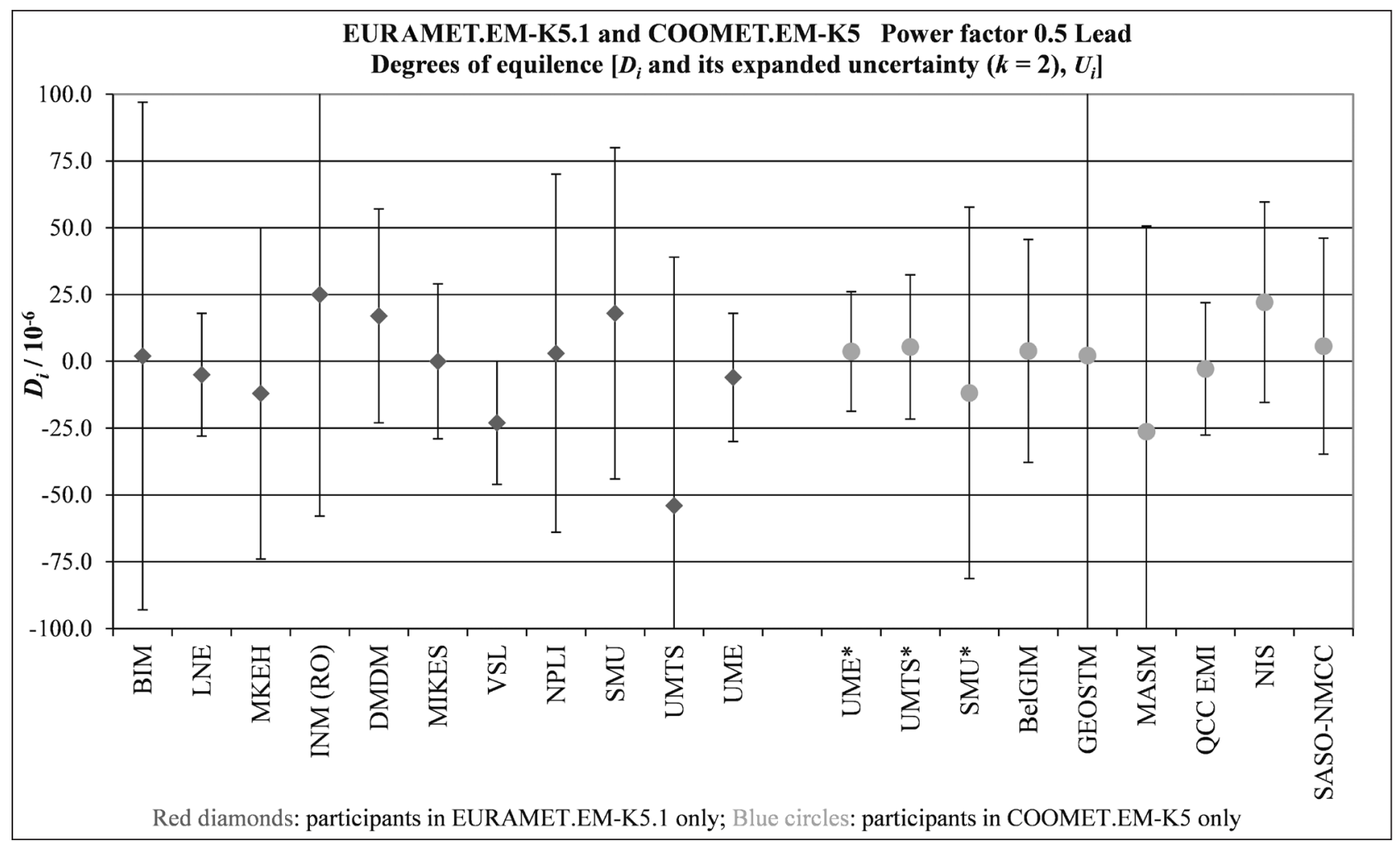

Fig. 3. DoE of NMIs/DIs in EURAMET.EM-K5.1 and COOMET.EM-K5 KCs in terms of RV $\mathrm{K}_{5}$ for PF 0.5 Lead

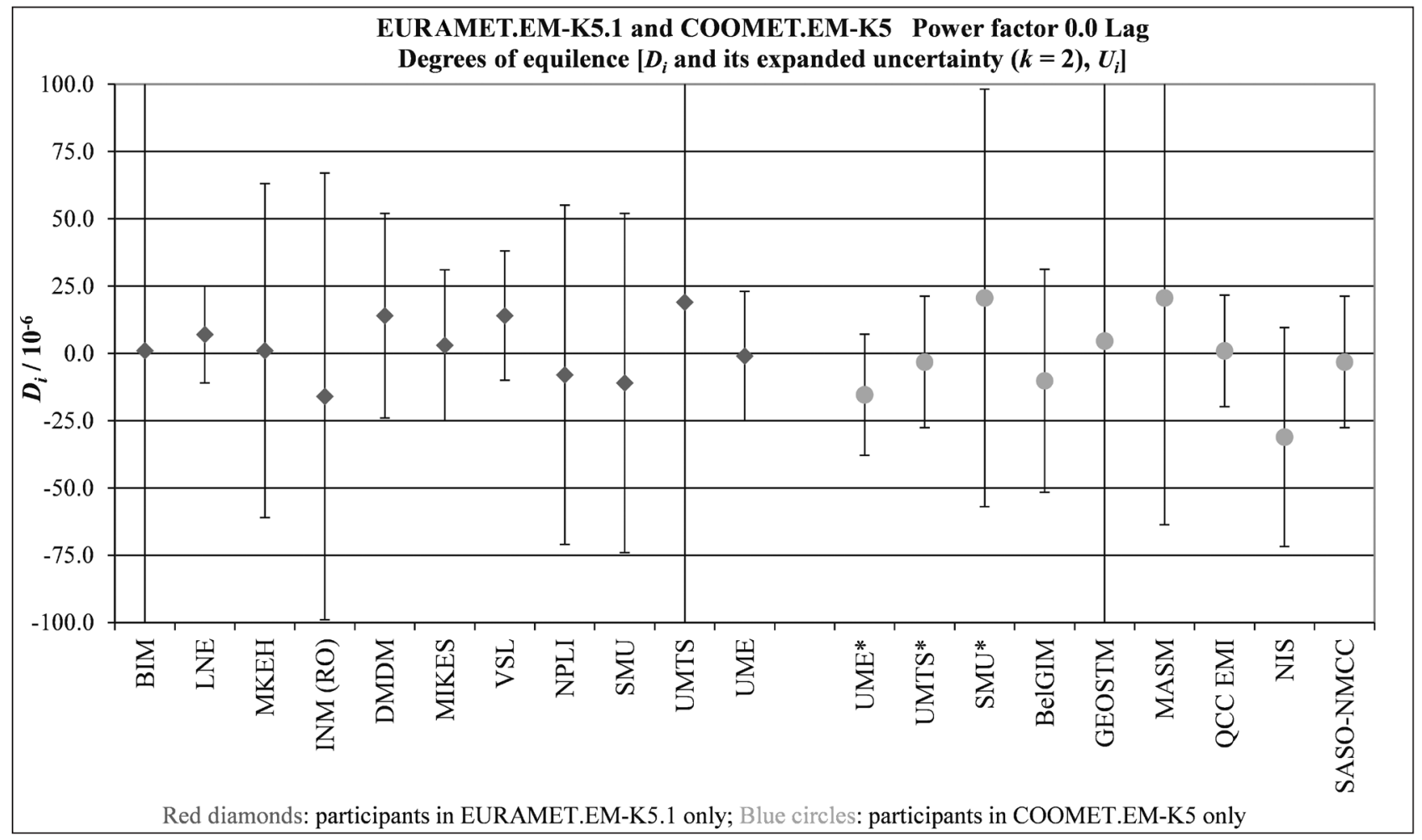

Fig. 4. DoE of NMIs/DIs in EURAMET.EM-K5.1 and COOMET.EM-K5 KCs in terms of RV $\mathrm{K}_{5}$ for PF 0.0 Lag 


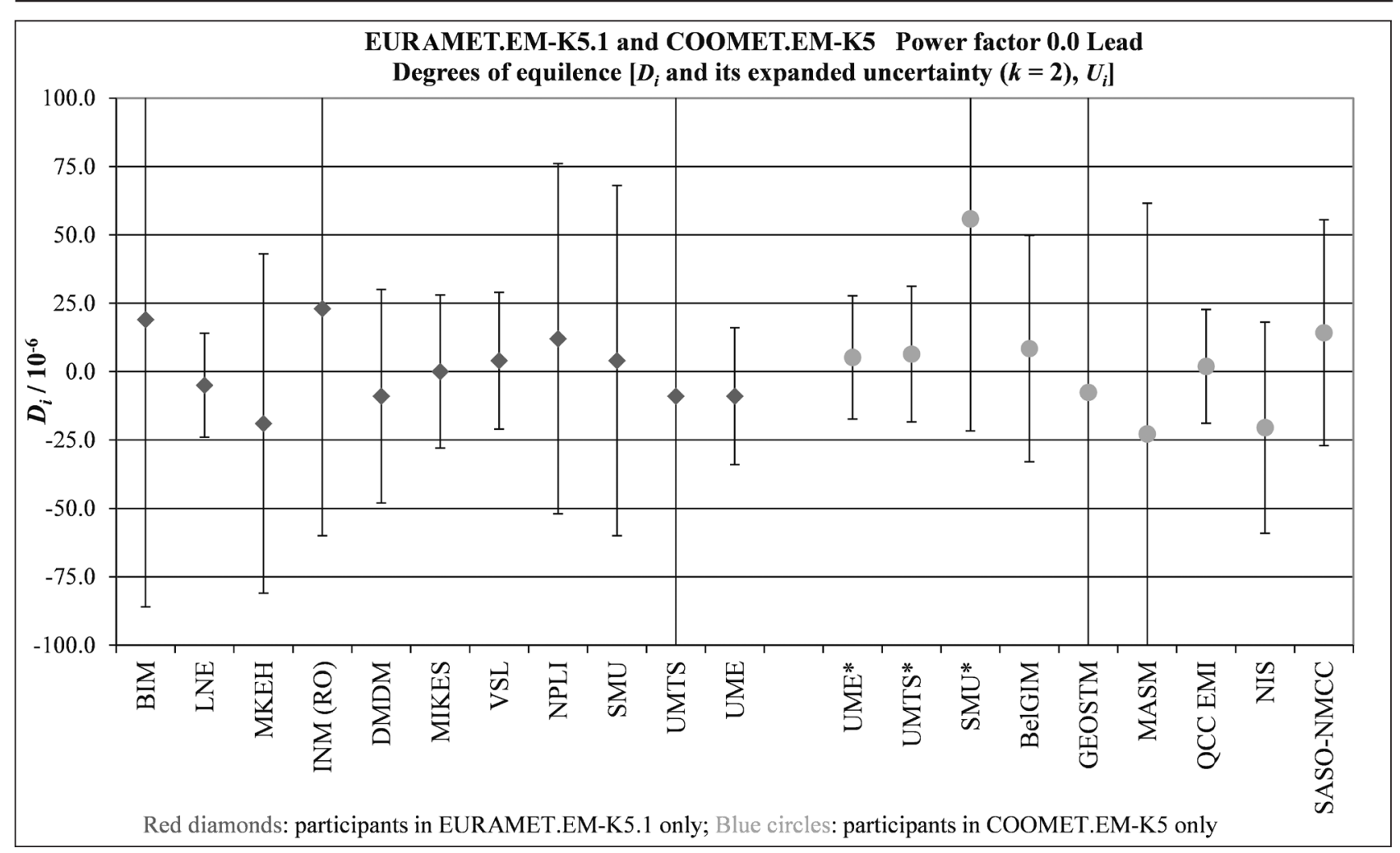

Fig. 5. DoE of NMIs/DIs in EURAMET.EM-K5.1 and COOMET.EM-K5 KCs in terms of RV $\mathrm{K}_{5}$ for PF 0.0 Lead

Table 4 are much better than in EURAMET.EM-K5.1 KC

DoE difference and DoE uncertainty difference of NMIs/DIs in EURAMET.EM-K5.1 and COOMET.EM-K5 KCs

\begin{tabular}{|c|c|c|c|c|}
\hline \multirow[t]{2}{*}{ NMI/DI } & $\begin{array}{c}\Delta_{\mathrm{RK}}, \\
\mu \mathrm{W} /(\mathrm{VA})\end{array}$ & $\begin{array}{c}\Delta U_{\mathrm{RK}}, \\
\mu \mathrm{W} /(\mathrm{VA})\end{array}$ & $\begin{array}{c}\Delta_{\mathrm{RK}}, \\
\mu \mathrm{W} /(\mathrm{VA})\end{array}$ & $\begin{array}{c}\Delta U_{\mathrm{RK}}, \\
\mu \mathrm{W} /(\mathrm{VA})\end{array}$ \\
\hline & \multicolumn{2}{|c|}{$\mathrm{PF}=1.0$} & \multicolumn{2}{|c|}{$\mathrm{PF}=0.5 \mathrm{Lag}$} \\
\hline UME* & -6 & 2 & -21 & -2 \\
\hline UMTS* & -14 & -9 & -81 & -66 \\
\hline SMU* & -66 & 0 & -8 & 8 \\
\hline NMI/DI & \multicolumn{2}{|c|}{$\mathrm{PF}=0.5$ Lead } & \multicolumn{2}{|c|}{$\mathrm{PF}=0.0 \mathrm{Lag}$} \\
\hline UME* & 10 & -2 & -14 & -2 \\
\hline UMTS* & 59 & -66 & -22 & -131 \\
\hline SMU* & -30 & 8 & 32 & 15 \\
\hline NMI/DI & \multicolumn{2}{|c|}{$\mathrm{PF}=0.0 \mathrm{Lead}$} & \\
\hline UME* & 14 & -3 & - & - \\
\hline UMTS* & 15 & -122 & - & - \\
\hline SMU* & 52 & 14 & - & - \\
\hline
\end{tabular}

Results UME (Turkey) in EURAMET.EM-K5.1 and COOMET.EM-K5 KCs are quite stable, taking into account the time drift between comparisons (DoE uncertainty difference from 2 to $-3 \mu \mathrm{W} /(\mathrm{VA})$ ). Results UMTS (Ukraine) in COOMET.EM-K5 KC
(DoE uncertainty difference from -9 to $-131 \mu \mathrm{W} /$ (VA)), since a significant modification of the national measurement standard of power was made. Results SMU (Slovakia) in COOMET.EM-K5 KC are worse than in EURAMET.EM-K5.1 KC (DoE uncertainty difference from 0 to $15 \mu \mathrm{W} /(\mathrm{VA}))$. It's may be due to the change of contact person in NMI.

\section{Conclusion}

KCs play an important role in internationally recognizing the measurement results of NMI/DI and achieving traceability of GMT. Obtained results for all NMIs/DIs of both KCs have good data consistency. Those KCs will be able to provide support CMCs entries for NMIs/DIs for power in Appendix C of the CIPM MRA.

The described procedure of linking of RMO KCs with respect to CCEM-K5 KC RV is used for linking results of EURAMET.EM-K5.1 and COOMET.EMK5 KCs for power at frequency $53 \mathrm{~Hz}$ for PF 1.0, $0.5 \mathrm{Lag}, 0.5 \mathrm{Lead}, 0.0 \mathrm{Lag}$, and $0.0 \mathrm{Lead}$. Special conclusions on the results of NMIs/DIs of the participants of both comparisons are presented. 


\title{
Можливості зв'язування результатів EURAMET і COOMET ключових звірень для потужності
}

\author{
О.М. Величко ${ }^{1}$, Т.Б. Гордієнко²
}

1 дП “Укрметртестстандарт”, вул. Метрологічна, 4, 03143, Київ, Україна velychko@ukrcsm.kiev.ua

2 Одеська державна академія технічного регулювання та якості (ОДАТРЯ), вул. Ковальська, 15, 65020, Одеса, Україна

t_gord@hotmail.com

\section{Анотація}

Результатами реалізації Угоди про взаємне визнання Міжнародного комітету з мір та ваг (CIPM MRA) є міжнародно визнані калібрувальні та вимірювальні можливості (СМС) учасників міжнародних звірень. Ключовими звіреннями (К3) еталонів є спеціальні звірення для національних метрологічних інститутів (HМI) і призначених інститутів (ПІ) у рамках Консультативних комітетів (КК) СІРМ і регіональних метрологічних організацій (РМО). К3 РМО еквівалентні К3 КК.

Подано основні результати НMI та ПІ, які вимірюють потужність у рамках К3 EURAMET.EM-K5.1 та COOMET.EM-K5. У K3 EURAMET.EM-K5.1 взяли участь 12 HMI/ПI, а пілотною лабораторією був UME (Туреччина). У К3 СООМЕТ.ЕМ-К5 взяли участь 13 НMI/ПI, а пілотною лабораторією був UMTS (Україна). UME, UMTS та SMU (Словаччина) взяли участь у обох K3.

Для досягнення глобальної метрологічної простежуваності доцільно використовувати методологію зв'язування результатів К3 РМО до К3 КК. Описано процедуру зв'язування К3 РМО до опорного значення К3 КК, яку може бути використано для практичної оцінки результатів конкретних КЗ РМО для розширення технічної бази підтвердження СМС НМІ та ПІ.

Подано зв'язані результати ключових звірень EURAMET.EM-K5.1 і COOMET.EM-К5 для потужності на частоті 53 Гц та коефіцієнтів потужності 1.0, $0.5 \mathrm{Lag}, 0.5 \mathrm{Lead}, 0.0 \mathrm{Lag}$ та $0.0 \mathrm{Lead}$. Подано спеціальні висновки щодо результатів UME, UMTS та SMU, які брали участь в обох К3. Встановлено, що UME мав стабільно хороші результати в обох звіреннях, UMTS значно поліпшив свої результати в останньому звіренні, а SMU дешо погіршив результати. Нових результатів UMTS досягнуто за рахунок суттєвої модернізації національного еталона потужності.

Ключові слова: ключові звірення; опорне значення; невизначеність вимірювань; національний метрологічний інститут; зв'язування.

\section{Возможности привязки результатов EURAMET и СООМЕТ ключевых сличений по мощности}

\author{
О.Н. Величко ${ }^{1}$, Т.Б. Гордиенко 2 \\ 1 ГП “Укрметртестстандарт”, ул. Метрологическая, 4, 03143, Киев, Украина \\ velychko@ukrcsm.kiev.ua \\ 2 Одесская государственная академия технического регулирования и качества (ОГАТРК), ул. Ковальская, 15, 65020, \\ Одесса, Украина \\ t_gord@hotmail.com
}

\section{Аннотация}

Результатами реализации Соглашения о взаимном признании CIPM (MRA) являются международно признанные возможности калибровки и измерений (CMC) участников сличений. Представлены основные результаты лабораторий-участниц национальных метрологических институтов (НМИ) и назначенных институтов (НИ), которые измеряют одинаковую мощность в рамках ключевых сличений (KC) EURAMET.EM-K5.1 и COOMET.EM-K5. В КС EURAMET.EM-K5.1 приняли участие 12 НМИ/НИ. В работе СООМЕТ.ЕМ-К5 КС приняли участие 13 НМИ/ НИ. UME (Турция), UMTS (Украина) и SMU (Словакия) были общими участниками KC EURAMET.EM-K5.1 и COOMET.EM-K5. 
Для достижения глобальной метрологической прослеживаемости целесообразно использовать методологию привязки результатов КС Консультативных комитетов (КК) и КС региональных метрологических организаций (PMO). Описана процедура привязки КС РМО по опорному значению КС КК. Представлены связанные результаты EURAMET.EM-K5.1 и COOMET.EM-K5 для мощности. Представлены специальные выводы по результатам UME, UMTS и SMU, которые участвовали в обоих КC.

Ключевые слова: ключевые сличения; опорное значение; неопределенность измерений; национальный метрологический институт; привязка.

\section{References}

1. Bureau International des Poids et Mesures. Mutual Recognition of National Measurement Standards and of Calibration and Measurement Certificates issued by National Metrology Institutes (CIPM MRA 1999, revision 2003).

2. Velichko O.N. Traceability of measurement results at different levels of metrological work. Measurement Techniques, 2009, vol. 52, pp. 1242-1248.

3. CIPM MRA-D-05. Measurement comparisons in the context of the CIPM MRA. 2016. 29 p. Available at: http://www.bipm.org/en/cipm-mra/ cipm-mra-documents/

4. Cox M.G. The evaluation of key comparison data: determining the largest consistent subset. Metrologia, 2007, vol. 44(3), pp. 187-200. doi: 10.1088/0026-1394/44/3/005

5. Elster C., Toman B. Analysis of key comparison data: critical assessment of elements of current practice with suggested improvements. Metrologia, 2013, vol. 50, pp. 549-555. https://doi. org/10.1088/0026-1394/50/5/549

6. Velychko O., Gordiyenko T. The estimation of the measurement results with using statistical methods. Journal of Physics: Conference Series, 2015, vol. 588, 012017. 6 p. doi: 10.1088/1742$6596 / 588 / 1 / 012017$

7. The BIPM key comparison database (KCDB). Available at: http://kcdb.bipm.org/ (accessed 11.11.19).

8. COOMET R/GM/14:2016. Guidelines for data evaluation of COOMET key comparison. Available at: http://www.coomet.org/DB/isapi/cmt_ docs/2016/5/2BMD1O.pdf

9. CIPM MRA-D-04. Calibration and Measurement Capabilities in the context of the CIPM MRA.
Oct. 2013. 43 p. Available at: http://www.bipm. org/en/cipm-mra/cipm-mra-documents/

10. Velichko O. N. Calibration and measurement capabilities of metrological institutes: features of preparation, examination, and publication. Measurement Techniques, 2010, vol. 53(6), pp. 721-726.

11. Velychko O., Gordiyenko T. Metrological Traceability at Different Measurement Levels. In book: Standards, Methods and Solutions of Metrology. Edited by Luigi Cocco. Publisher: InTech, March 2019, pp. 1-21. doi: 10.5772/intechopen.84853

12. Velychko O. Possibilities of Linking Results of Key and Supplementary Comparisons in Field of Electricity and Magnetism. Measurement, 2019, 144, pp. 167-172.

13. Oldham N., Nelson T., Zhang N.F., Liu H.-k. Final Report of CCEM-K5 Comparison of 50/60 $\mathrm{Hz}$ Power. Metrologia, 2003, vol. 40, Technical Supplement, 01003. 28 p.

14. Çaycı H. EURAMET.EM-K5.1. Key Comparison of $50 / 60 \mathrm{~Hz}$ Power Final Report. Metrologia, 2011, vol. 48, Technical Supplement, 01009. 70 p.

15. Velychko O., Karpenko S. Final report on COOMET key comparison of power (COOMET. EM-K5). Metrologia, 2019, vol. 56(1A):136. doi: 10.1088/0026-1394/56/1A/01010

16. Velychko O., Karpenko S. Main Results of COOMET.EM-K5 Key Comparison of Power. Ukrainian Metrological Journal, 2019, no. 1, pp. 19-26. doi: 10.24027/2306-7039.1.2019.164610

17. Velychko O. Linking of Results of Key Comparisons CCEM-K5 and COOMET.EM-K5. Kyiv, Ukraine, SE "Ukrmetrteststandard", December 2018. 19 p. Available at: https://www.bipm.org/ $\mathrm{kcdb} /$ comparison $\mathrm{id}=428$ 